\title{
Social medicine and human development
}

\section{Opinion}

Human development has three components, life expectancy, income and level of education. We will make some comments on the three aspects, which are mixed in health. The health process has changed drastically, today, people want to be healthy to live, prosper, generate wealth and obtain happiness. The disease has ceased to be an important existential factor, because systems are the media systems of the health of human beings.

Fortunately, nature still modulates the existence of living beings. As finite beings we are born and die in the conditions that nature establishes and that is modified by the genes, the environment and our own decisions. ${ }^{1}$

At the end of the $60 \mathrm{~s}$ and the beginning of the $70 \mathrm{~s}$ it was determined that: Medical care is not the cause of improving the health of populations. We do not deceive ourselves, none can we ask for a society with big basic problems that are not solved, but cultural education and creativity is manifested, it is unfair to assimilate the basic concepts of self-care and personal responsibility, when we are hungry.

Most of the countries of Latin America that include a Mexico, have a great advance to maintain an epidemiological control of the pathologies that continue to end human lives in an absurd way.

Intestinal infections, tuberculosis, "toxemia", cervical cancer, malnutrition, maternal deaths due to birth complications, respiratory infections and the central nervous system, as well as some chronic and degenerative diseases, are now diseases social. It is derived from the social determinants and invariably go hand in hand with the poor educational quality of social groups, it does not mean that only the poor, the diseases do not discriminate "social environment", however, it is in the place of sight. Risk and the frequency of these pathologies is higher than populations without the possibility of solving the basic needs of food, housing, hygiene, public services and education.

When doctors touch these issues, we express an immense sadness when seeing people in the social structure to improve their living conditions.

When newborns die of meningitis, pneumonia, and diarrhea or see adolescent peasants of 13 or 14 years pregnant, women with 6 or 7 children who die from a complication of the part and leave their children orphans, or see how people are physically deteriorated in productive age or families for tuberculosis. You cannot be detached or indifferent to these situations.

The health system is fragmented systems inefficient, with serious problems of quality in services and with serious technological, technical and human resources lags. The evolution of science, technology, but above all of Human Rights, has exceeded the capacity of adaptation of our system, this does not allow to achieve a healthy society, which generates wealth and happiness.

Modern life has turned the world into a global village, technology allows a vertiginous communication, but only for economic, political and financial interests, human rights are pending.

\author{
Volume 3 Issue 6 - 2018 \\ Francisco Javier Posadas Robledo \\ Medical Surgeon, Autonomous University of San Luis Potosi, \\ Mexico
}

Correspondence: Francisco Javier Posadas Robledo, Medical Surgeon, Director of Operations Research, Autonomous University of San Luis Potosi, Mexico, Tel 52444I308597, Emailfposadazr@hotmail.com

Received: October 30, 2018 | Published: November 06, 2018

Our generation has turned the world into a small space, but only to maintain the interests of big investments, free trade and consumption. When it comes to human rights, equality and growth of human beings, segmentation, segregation and discrimination are exacerbated. Or walls are created that divide human beings. Our age will pay that historical cost. The social and collective response is a massive migration towards more equitable and fair systems. Evolved societies are in a modern struggle, where vulnerable social groups must be cared for and taken care of, by humanism. Generated by ineptitude and corruption of governments, political systems and less evolved societies. This is the struggle established in our 21 st century. Governments and systems of power, against the en masse masses of poverty that aspire to social justice and not only to consider them consumers of huge volumes of junk and garbage, which enrich the economic consortiums and maintain control of the inequality and concentrated wealth, regardless of the collective damage of human beings with unhealthy lifestyles, burdened by consumerism, which is encouraged by perverse advertising.

It is not new that wealth is concentrated in small human groups, but today more than ever technology, science and human rights must be the cornerstone of human thinking to achieve more just and equitable societies. From the scientific point of view, the concentration of wealth in a few hands is unacceptable, when great human nuclei of the world are struggling in misery.

There are many successful men and women in societies, businessmen, workers, professionals, workers, peasants, technicians, housewives, who maintain honesty as a principle, who are generators of wealth, who have earned every ounce of wealth, working, fighting, sometimes for several generations. However, they are not provided anything, generate wealth and this is distributed unevenly. The economically active population carries the full weight of the inactive country at the expense of diminishing its purchasing power, it is necessary to work many hours, many days and obtain meager salaries. The fundamental thing is to hierarchize social structures, to commit each social stratum to comply with its social and fiscal obligations so that with all the moral weight it exercises its rights.

The human development of modern societies necessarily involves a social structure that promotes human development. Health, education, housing, employment, social security and essential satisfaction resolved, is the basis for building just, creative, peaceful societies. In short, create and form citizenship. 
In the $21^{\text {st }}$ century, in the post-truth era, it would seem that the battles have won the things that have a price and not those that have value. Health is the most precious asset that a person has, comparable only with values such as freedom or education. Human beings should aim to ensure that everyone has access to these essential human rights. The other part of existential satisfactions, should be obtained based on effort and personal talent.

No sensible person should be against the distribution of wealth and social equity, but must be based on justice and the legitimate effort of each person. Taxes of taxpayers must be able to create favorable environments, solve social problems, and improve the economy, the dignity of people and the credibility of government systems, to achieve private investments with social commitment.

Health is a right that can be democratized and objectively reflects the will of the government and its health system to achieve social justice and the common good. Caring for people in a modern, equitable, financed and quality health system allows us to create a solid base to achieve social capital with a better future.

What is required is a cultural revolution that leads us towards an authentic democracy. That it forms citizens with human rights, with opportunities and a favorable environment to develop all their talents and abilities and that each person contributes, according to their capacities, the granite that generates better living conditions for their generation and the subsequent ones. ${ }^{2,3}$

\section{Acknowledgements}

None.

\section{Conflict of interest}

Author declares that there is no conflicts of interest.

\section{References}

1. Posadas RFJ. Pharmacology in the $21^{\text {st }}$ Century. J Pharmacol Clin Toxicol. 2017;5(6):1089.

2. K Vasudevo Roa. Atrophy to observe and hypertrophy of the instrumentation will symbolize the medicine of the year. Contemporary Hindu physician; 2000.

3. F Hegel (German philosopher). Experience teaches us that the people and their governments have never learned anything from history. 